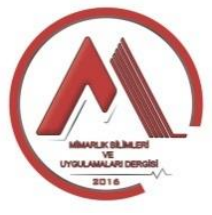

\title{
Meydanlardaki İsim Değişikliklerinin Kent Belleğine Etkisi: Ankara Örneği
}

\author{
Selin TURAN*, Özge YALÇINER ERCOŞKUN \\ Gazi Üniversitesi, Mimarlık Fakültesi, Şehir ve Bölge Planlama Bölümü, 06570, Ankara, Türkiye. \\ *e-mail:selinturan80@gmail.com
}

Öz

Kentsel kimlik, kentlerin kendilerine özgün değerlerinden oluştuğu için, kentlinin kent ile farklı etkileşimlerle bulunup yaşanmışlıkları arttırmasına, kent parçasını anılar üzerinden hatırlayarak, mekânı belli sembollerle anımsamasına ve bu sayede kentsel belleğin oluşmasına olanak sağlamaktadır. Şehirler dönemin iktidarına, ideolojilerine ve tarihi, kültürel ve sosyal değerlerine yönelik metinlerden oluşur. Adlandırma şehirsel metinlerin okunmasını sağlamaktadır. Kentsel belleğin oluşması için fiziksel mekânın yanı sıra sosyal açıdan mekân üzerindeki anıların etkili olması sokak, cadde ve meydan isimlendirmelerinin önemini arttırmış, bu şehirsel toponimi kavramının gelişmesini sağlamıştır. Günümüzde isimlendirme çalışmaları geleneksel işlevine ek olarak farklı anlamlar kazanmıs, meydan isimlendirmesi farklı algılar yaratmak amacıyla kullanılır hale gelmiştir. Bu çalışma Ankara'daki Kızılay Meydanı, Anadolu Meydanı ve Tren Garı Meydanı'nda yapılan anket çalışmaları üzerinden, meydana gelen isim değişikliklerinin kent belleğine etkisini araştırıp, bellek mekânlarına yapılan müdahalelerin kentli tarafından ne ölçüde bilindiğini ve bu müdahalelerin kentli tarafindan ne derecede benimsendiğini saptamayı amaçlanmakta, değişikliğin hangi etkenlere bağlı ve hangi şartlarda kent belleğinde yer edebileceğini ortaya koymaktadır.

Anahtar Kelimeler: Kent belleği, kentsel toponimi, meydan isimleri, Ankara.

\section{The Impact of Name Changes on the Urban Memory: A Case Study on Ankara}

\begin{abstract}
Urban identity is created from unique values of cities which provides interaction between city and citizens, increase life experience, memories on urban fragments, recalls the space with specific symbols and thus enables creating urban memory. Cities consist of texts about the potency of the era, ideologies and their historical, cultural and social values. Naming provides urban reading. In order to form urban memory, beside the physical space, the impact of memories on space increase the importance of street and square names, thus improving the concept of urban toponomy. Today, studies on naming gain different meanings onto their traditional function, and naming squares come into use in order to create different perceptions. The aim of this study is to search the impact of name changes on the urban memory according to survey results in 15th of July Kizllay National Will Square, Anadolu Square, Train Station Square in Ankara. The study presents the extent of interventions and the conditions leave marks on the urban memory.
\end{abstract}

Keywords: Urban memory, urban toponomy, square names, Ankara

\section{Giriş}

Her kent kendine özgü farklı kimliklere, farklı ruhlara ve dillere sahiptir. Kenti anlamak kimliği oluşturan bileşenleri görüp bu bileşenlere sahip çıkmakla ve o ruhu hissedip o dili çözmekle mümkündür. Kent kimliğine etki eden doğal, yapay, beşeri birçok etkenden söz edilebilir. Fakat bunların başında insan ve insanın kentle kurduğu ilişki gelmektedir. Çünkü kent parçasının mekâna dönüşümü insanla olmaktadır. 
Kentin dinamik yapısı kent kimliğini de etkiler. Geçen zamanla, kentteki değişim ve dönüşüm süreçleriyle kentsel kimlik kavramı da değişikliğe uğramış ve farklı bakış açılarıyla ele alınmıştır. Kentsel kimlik kentlerin özgün değerlerinden oluştuğu için, kentlinin kent ile farklı etkileşimlerle bulunup yaşanmışıkları arttırmasına, kent parçasını anılar üzerinden hatırlayarak, belli sembollerle anımsamasına ve bu bağlamda kentsel belleğin oluşmasına olanak sağlamaktadır.

Kentsel bellek, fiziksel mekânın yanı sıra sosyal anlamda mekân üzerindeki anılardan oluştuğu için kentli ile mekân arasındaki ilişkiyi şekillendirmede sokak, cadde ve meydan isimlendirmeleri önem kazanmaktadır. İnsanoğlu var olduğundan bu yana adlandırma eylemine ihtiyaç duymuştur. Yaşanılan ortamdaki çeşitli objelerin adlandırıması, o objelerin coğrafi mekânla bütünleşmesine olanak sağlamış, bu sayede objeler birbirinden ayırt edilebilir hale gelerek kişilik kazanmış ve konumlar yere dönüşmüştür.

Kentler, sadece insan eliyle oluşturulmuş yapılı çevreler değildir. Kentler farklı ruha sahip olduğu için, dönemin iktidarına, ideolojilerine ve kültürel değerlerine yönelik yansımalar içerir. Bu bağlamda kenti anlamada cadde, sokak ve meydan adları önemli yere sahiptir. Bu doğrultuda çalışmanın amacı; Ankara'daki üç meydan üzerinden kentte meydana gelen isim değişikliklerinin kent belleğine etkisini araştırıp, bellek mekânlarına yapılan müdahalelerin kentli tarafından ne ölçüde bilindiğini ve bu müdahalelerin kentli tarafından ne derecede benimsendiğini saptamayı amaçlanmaktadır.

Çalışmanın yöntemi; kent kimliği ve isim değişikliğinin kent kimliğine etkisi ile ilgili literatür araştırmasıyla birlikte yürütülmüş olan üç örneklem alanında yüz yüze anket çalışmaları yapılarak nicel ve nitel verilere erişilmesidir. Yapılacak olan anket çalışmasında her meydan için farklı kullanıcıların (öğrenci, çalışan, emekli), her yaş grubundan ve cinsiyetten eşit olarak seçilmesi sağlanarak, üç meydanda toplamda 100 adet anket yapılarak değerlendirilmiştir.

Çalışma, meydanlardaki isim değişikliklerinin kent belleğine etkisini kapsamaktadır. Çalışmanın birinci bölümü kent kimliği kavramını, kentsel kimlik bileşenlerinden beslenen kentsel bellek ve kentsel toponimi ilişkisini içeren literatür araştırmasından, ikinci bölümü ise Kızılay, Tandoğan ve Ankara Garı Meydanlarında ki isim değişikliğinin kent belleğine etkisine yönelik saha araştırmasından oluşmaktadır.

Bu doğrultuda birinci bölümde kimlik ve kentsel kimlik kavramları açıklanmış, kentsel kimliği oluşturan bileşenler sıralanmıştır. Ardından kentsel bellek, şehirsel toponimi kavramlarını açıklanmış, kent mekânlarına yapılan müdahaleler doğrultusunda isim değişikliği ile toponimi arasındaki ilişki anlatılmıştır. Çalışmanın ikinci bölümünde ise literatür araştırmaları kapsamında Ankara'da bellek mekanı olarak nitelendirilen ve son zamanlarda isim değişikliğine uğrayan üç meydan örnek alanlar olarak belirlenmiş ve uygulanan isim değişikliğinin kentlinin ne oranda farkında olduğunu saptamaya yönelik anket çalışması yapılmıştır. Bu meydanlar; Ankara kent merkezindeki en önemli yer olan Kızılay Meydanı, kentin mitinglerine ev sahipliği yapan Tandoğan Meydanı ve bulunduğu konum ve garın etrafında olması nedeniyle önemli bir tarihsel yere sahip olan Tren Garı Meydanı'dır. Bu meydanlarda farklı kullanıcılarla yapılan anketler sonucu, meydana gelen isim değişikliklerinin kentli tarafından ne kadar benimsendiği ve yapılan isim değişikliklerinin kent belleğini ne yönde etkilediğine dair değerlendirme yapılmaktadır. Çalışmanın sonunda kentsel bellek ve kentsel toponimi üzerine değerlendirme yapılmaktadır.

\subsection{Kimlik ve Kentsel Kimlik Kavramı}

Kimlik, doğadaki herhangi bir varlı̆̆ın başka varlıklardan ayrılan özelliklerinin ifadesi, onun kendine özgü olma durumudur. Kendine özgü olma durumu diğer varlıklarla kurulan ilişkilerle anlaşılabildiğinden, ilişki, kimliği ortaya çıkaran eylem biçimidir. Kimlik bir varlığın kendisini ifade etmesiyle ilgili olduğu için temsil niteliği taşımaktadır (Güvenç, 1995; Lynch, 1965 ve 1981; Proshansky, 1983).

Toplumda her birey kendi kimliğini oluşturmaktadır. Bireyler arasındaki farklılaşma ile değişkenlik ortaya çıkmakta, bu değişkenlik toplumun yaşadığı çevreye de yansımaktadır. Kimlik, bir nesnenin diğer nesnelerle arasındaki fark edilebilir olma durumudur. Kimlik; ait olduğu topluma kaybolmuşluk 
hissi değil, güven oluşturma hissi vermekte ve bu duyguyu da sürekli dönüşüm içerisinde geliştirmektedir (Aykut,1998).

Kimlik, sadece bireylerin değil, çevrenin, toplumun ve kentlerin de kendilerini ifade etmede kullandığı bir araçtır. En küçük ölçekten en büyük ölçeğe doğru bireysel, grup, toplumsal ve ulusal kimlik, ulusal kimliğin altında çevresel kimlik ve çevresel kimliğin de altında mimari kimlik, mekânsal kimlik ve kentsel kimlik olmak üzere farklı boyutlarda incelenebilir.

\subsubsection{Kentsel Kimlik}

Kimlik bir kentin görüntüsüdür. Bir kentin kimliği uzun süre içinde şekillenir. Coğrafyası, tarihi, kültürel değerleri ve düzeyi, mimarisi, içinde yaşayan uygarlıkları, yerel gelenekleri, yaşam biçimi, şu anda yaşayan insanları, ilk yerleşimden bugüne geçirdiği evreleri kent kimliğinin bileşenleridir. Ayrıca topoğrafyası, bitki örtüsü, iklimi, jeopolitik konumu, Doğu veya Batı kenti oluşu, deniz ve karayolu bağlantısı, başka kültürlere olan açıklığı veya kapalıı̆ı, ekonomik yapısı, barındırdığı canlı türleri, geçirdiği işgaller ve savaşlar, depremler, bir devlete başkentlik yapıp yapmadığı gibi kentin fiziksel özelliklerinden, doğal dokusundan, sosyal yapısından, tarihi ve kültürel miraslarından doğan etkenlerle bir kentin kimliği tanımlanır. Bu özelliklerin farklılaşması kentlere özgün karakter kazandırır.

Kentsel kimlik, bir kenti tanımlayıp diğerlerinden ayıran, belirleyici nitelikteki bileşenler bütünüdür. Kent kimliğini, şehirdeki değişimler ve değişkenler olduğu kadar, sabit değişmezler de oluşturmaktadır. Birey ve çevresi arasındaki ilişkinin karşılıkı ve devamlı olması mekâna yüklenen anlamların da sürekliliğini sağlar (Ocakçı, 1993).

Kentsel kimlik, toplum tarafından şekillenen kentin kendine özgü değerlerinden oluşur. Bu kapsamda Correa (1983), kimliğin bir süreç olduğuna değinerek, kimliğin üretilemeyeceğini savunmaktadır. Gürsel (1993)'e göre kimliğin sürecini oluşturan faktörler kültürel miras veya gelenekler, toplumun değişen gereksinimlerinin nitelikleri, doğal faktörlerden kaynaklı fırsatlar ve kısıtlamalar, teknolojideki gelişmelerdir.

Kentsel kimlik, bir kentin veya çevrenin coğrafi, iklimsel, folklorik, sosyo-kültürel yapısı veya kendine özgü anıt yapıları, meydanları ve sokaklarıyla oluşmaktadır (Hacıhasanoğlu, 1995). Ocakçı (1995)'ya göre kent kimliğini oluşturan elemanlar; doğal çevreden kaynaklanan kimlik elemanları, beşeri çevreden kaynaklanan kimlik elemanları ve insan eliyle inşa edilmiş çevreden kaynaklanan kimlik elemanları olmak üzere üç sınıfta incelenebilir. Doğal çevreye yönelik veriler topografya, bitki örtüsü, iklim koşulları ve jeolojik durumu hakkındaki verileri kapsamaktadır. Beşeri çevre ise, birey ve toplum arasındaki etkileşimden oluşmaktadır.

Kent dinamik bir yapıya sahiptir. Bu dinamikliği sağlayan yalnızca zamanla değişiklik gösteren bileşenler ve süreçler değil, insanın kentle kurduğu etkileşim, ona yüklediği anlamlardır. Bu doğrultuda; bir kentin kimliğini, alt ölçekte yapıların sadece mimari değerinde veya üst ölçekte doğal ve yapay çevrede aramaya çalışmak yeterli değildir. Bu özellikler ancak, içinde geçirilen yaşam deneyimleri ile insanla etkileşime geçtiği ölçüde anlam ve değer kazanmaktadır. Bu etkileşimin sağlanması, kentlerin fiziki ve kültürel sürekliliğini sağlamak ve kentlinin belleğinde yer etmesi açısından önem taşımaktadır.

Örer (1993) ve Relph (1976) araştırmalarını, kentsel kimliğin alışılagelmiş yanları dışında farklı boyutlarda incelemiş, insanın bireysel bilgi ve kültürel donanımın, zevk ve tercihlerinin kenti anlamada ve kent kimliği oluşturmada farklıklara yol açtığından söz etmişlerdir.

Örer (1993)'e göre kent sadece en, boy, yükseklik ve zamandan oluşan dört boyutlu bir şemayla tarif edilemez. Kentte, insanın algı-sezgi ile kavradığı, bilgi birikimi, deneyimi, kültürü ile çok yönlü değerlendirdiği daha birçok unsurdan oluşan gizli-açık mesajlar vardır ve bu mesajlar kent kimliğinin oluşmasında oldukça etkili olmaktadır.

Relph (1976)'e göre bir yerin kimliğini, mekânı deneyimleyen bireyin niyeti, kişilikleri ve şartlarına göre çeşitlenir. Bir kentin kimliği fiziksel ve kültürel birikimi ile o kentte yaşayan ve kentten 
yararlanan insanlar tarafından şekillenir. Bu nedenle, kent kimliği çalışmalarında, kentin fiziksel ve toplumsal dinamikleri etkileşim içinde düşünülmelidir.

Kenti oluşturan bileşenlerin farklı ölçeklerde incelenmesi, kent kimliğine etki eden bileşenlerin de mekânsal olarak gerek yerleşim ölçeğinde, gerekse bina ölçeğinde incelenebileceğini ortaya koymaktadır. Lefebvre (1996), mekânın çeşitli üretimlerinin farklı toplumsal ve yaratıcı düzenlemeleri ifade ettiğini, bu farklılıklarla toplumların kendilerine özgü kimliklerinin oluştuğunu ve bu doğrultuda mekândaki üretim biçimlerinin de değişikliğe uğradığını belirtmektedir. Bu da özgün bir form ya da yerleşme düzenine sahip kentlerin oluşmasına olanak sağlamaktadır. Dolayısıyla kentin yaşam biçimi ve kültürel yapısı kimliğinin oluşmasında önemli bir bileşendir. Tüm bu araştırmalardan yola çıkılarak bir kentin kimliğinin; kentin doğal, sosyal, kültürel, ekonomik ve yapılaşmış çevresinin mekânsal öğeleri ile bir bütün olarak değerlendirilmesi gerekmektedir. Bu doğrultuda, kent kimliği bileşenleri, aşağıdaki şekilde görüldüğüü üzere sınıflandırılmıştır (Şekil 1).

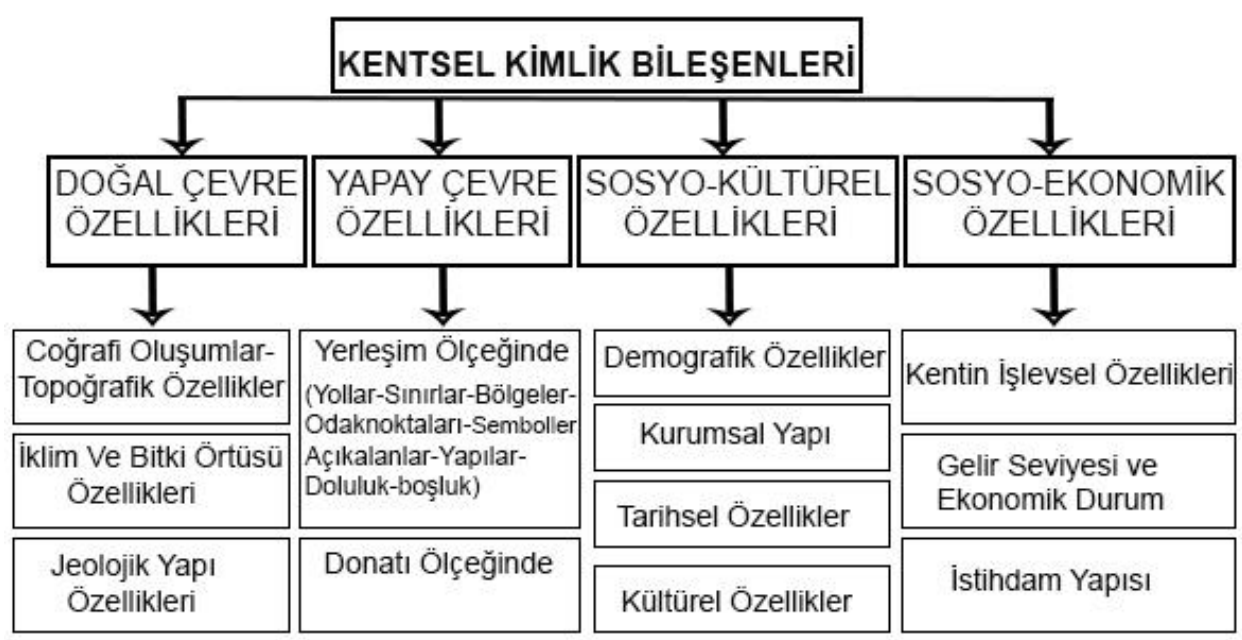

Şekil 1. Kentsel kimliği oluşturan bileşenler (Topçu, 2011)

\subsection{Kent Belleği ve Şehirsel Toponimi (Hodonimi)}

Bellek kimlikten beslenen bir olgudur. Bu doğrultuda bellek zaman içinde değişiklik gösteren koşul ve şartlara göre farklı şekillerde karşımıza çıkmakta ve şimdiki zamana göre şekil almaktadır (Gönül ve Çakır, 2015).

Halbwachs'in (1992) belleğin kolektif olarak oluşturulduğuna dair ifadesi, bireyin yapılı çevre ile etkileşiminin bellek bağlamında incelenmesine sebep olmuştur. Levent'e (2016) göre kentin tamamı kolektif belleği oluşturmaktadır. Kente dair her parça kent belleğinin bir parçasını oluşturmaktadır. Mekân üzerinde gelişen her sosyal ilişki, mekânın belleğine eklemlenmektedir. Derinleşen sosyal ilişkiler mekânın ruhunu oluşturmakta, kentsel belleği güçlendirmektedir. Kamusal alanların insanla kurduğu temas, mekânın yaşanmışlıkları biriktirilmesine olanak sağlamakta, bu süreç boyunca bireysel bellek toplumsal belleğe dönüşmüş olmaktadır (Madanipour, 2010).

Mekân kullanıcıların kişisel özelliklerinden dolayı farklı algılanmaktadır. Belleği oluşturan da bu algılardır. Kullanıcı, bellekte yer eden mekânı imgeye dönüştürerek ona aidiyet kazandırmaktadır (Gönül ve Çakır, 2015). Böylece insan bir süre sonra, duyumsal ve deneyimsel algıladığı mekânı içgüdüsel olarak sahiplenmeye başlamaktadır. Bu, mekâna yüklenen anlamların kentsel bellek üzerindeki önemini göstermektedir.

Toplumların belleğinde yer eden yaşanmışlıkları içinde barındıran, saklayan, yeniden üreten, yeniden sunan en önemli unsurlardan birisi mekândır. Mekân, toplumsal belleğin deposudur. Pösteki'ye (2012) göre bellek geçmişin zihinde depolanmasını ve hatırlama ile gün yüzüne çıkmasını sağlayan bir araçtır ve mekânın bellek ile ilişkisi, toplumsal belleği oluşturur. Mekân, kişinin bireysel hafızası görevini görür, duygu ve hatırlama eylemleriyle toplum arasında bir bağın kurulmasına olanak sağlar. 
Bu kapsamda mekânın olağandışı bir müdahaleye maruz kalarak değişime uğraması toplumsal belleğin oluşmasına sağlayan bağın kopması demektir.

Levent'e (2016) göre mekân yaşanmışlıklar, içerdiği anılar ve kendisine yüklenen anlamlar ile geçmiş ve gelecek arasında bir bağ görevi gördüğü için, mekânın içerdiği bu anlamları nesilden nesile aktarır. Mekânda gerçekleşen ilişkilerin sürekli olması, mekânın da sürekli olmasına ve bu durumun mekânı koruma ihtiyacının gelişmesine neden olmaktadır.

Kent belleğini oluşturan parçalar herhangi bir kamusal alandan, sokaktan, yapıdan veya bir anıdan oluşabilir. Bir mekânın bellek mekân olması için anıtsal ya da estetik bir değere sahip olmasına gerek yoktur (Hartmuth, 2010). Bu doğrultuda isimlendirme kentsel bellek kapsamında önem kazanmaktadır.

Toponimi yerleşme yerleri veya herhangi bir fiziki özelliğe verilen adları farklı yönleriyle (anlam, oluşum, köken ve dağılış gibi) ele alan, ad biliminin içinde yer alan bir alt bilim dalıdır. Cadde, sokak vb. ulaşım yollarının adları toponiminin altında hodonimi'nin (kentsel toponimi) konusudur. İnsanoğlu var olduğundan bu yana adlandırma eylemine ihtiyaç duymuştur. Yaşanılan ortamdaki çeşitli objelerin adlandırıması o objelerin coğrafi mekânla bütünleşmesine olanak sağlamıştır. Bu sayede objeler birbirinden ayırt edilebilir hale gelerek kişilik kazanmakta ve mekânlar yere dönüşmekte ve kent belleği oluşmaktadır. Tuan'ın (2005), yerin kişiliğinin doğal özellikler ile insanın meydana getirdiği düzenlemelerden oluştuğu yargısından yola çıkılacak olunursa, insan neslinin yaptığı düzenlemelere bir örnek de yer adlarıdır. Adlandırma iki boyutta incelenebilir. Birinci boyut cadde, sokak ve meydan adlarının neyi ifade edip topluma neyi hatırlattığıyla ilgilidir. İkinci boyut ise bu hatırlatmanın dışında adlandırmanın arka planında yer alan siyasi güç ve politik mücadeleyi kapsamaktadır. Cadde adları mekân üzerinde etkinlik sağlanmasında ve ortak bellek oluşturulmasında araçtır (Kooloos 2010, Azaryahu 2009: 316).

Şehirler, sadece insan eliyle yapılmış yerleşmeler değildir. Şehirler, ideolojilerin tasarlandığı, kültürel değerlerin ifade edildiği, iktidarın mekân üzerinde algısal denetime sahip olduğu konumlardır (Hall, 2001; Çelik, 2007). Bu özellikler kentin veya kent parçasının, kentlinin belleğinde yer etmesine olanak sağlar. Duncan (1990) şehirleri metin olarak ele almıştır. Bu metnin cadde ve sokak adları ile okunması, kentsel belleğin oluşmasında önem kazanmaktadır. Şehir içinde, şehrin önemli elemanları olan cadde, sokak ve meydan adları tarihe ışık tutmakta ve onu kullananların tavır ve kültürleri hakkında bilgi vermektedir.

Her şehir, cadde ve sokaklarla doludur. Onlar, insanların günlük faaliyetlerini yerine getirdikleri yerlerdir. Çelik (2007:127)'in "sokaklar-caddeler hem bir tasarım ürünü hem de sosyal yaşamın mekânıdırlar... Herhangi bir caddenin kendine özgü nitelikleri yani adları... onu oluşturan toplumsal, siyasal, teknik ve sanatsal güçlerin karmaşık bir bileşimi olarak ortaya çıkar" ifadesi, sokaklara verilen adların şehirler için politik ve ideolojik farklı mesajlar içerdiğini göstermektedir.

Şehirsel metni oluşturan elemanlar dinamiktirler. Bu dinamikliği sağlayan etkenler; yerleşmelerin ve o yerleşmedeki yaşayanların tarihi, coğrafi kökeni, gelişiminde önemli olan kişileri, olayları, soy bağları ve güvenlik şartlarındaki değişim ve politik düzenin mekâna yansımasıdır (Aliağaoğlu ve Yiğit, 2013). Bütün bu değişim ve dönüşümlere bağlı olarak kentsel toponimi şekillenmekte, bölgeden bölgeye değişiklik göstermektedir. Avrupa ülkelerinde adlandırma yapılırken sokağın boyutu etkenken, Amerika'da kullanım sıklığı etkendir. Türkiye'ye bakıldığında ise tarihi önemi olan kişilerin ve yerlerin adlandırmalarda büyük bir etken olduğu görülmektedir (Ayataç ve Araz, 2016).

'Yer Adları Sempozyumu' sonucunda ortaya çıkan genel olarak dünyadaki yer adları tasnifi aşağıdaki şekilde yapılmıştır.

1. Yeni keşfedilen yerlerde bilinmeyen şartlarla karşılaşmak korkusu, tehlikeli sürprizler, kâşif ya da göçmenlerin buralara dini isimler vermeye sevk etmiştir. Bunlar Hz. İsa, Hz. Meryem ve Hıristiyan Azizlerine ait isimlerdir. St. Louis, Santa Cruz...

2. Çeşitli ülkelere çeşitli sebeplerle göçenler geldikleri yerlere kendi eski yurtlarının adlarını vermişlerdir. New York, New Lizbon, New Amsterdam, New London, New Zeland, New Orleans... 
3. Yeni keşfedilen yerlere kâşiflerin isimleri verilmiştir. Hudson, Colombia...

4. Kâşiflerin mensup oldukları devletin hükümdarlarının veya yöneticilerinin isimleri verilmiştir. Victoria, Nelson...

5. İlim, sanat veyahut başka suretlere tanınmış şahsiyetlerin isimleri de yer adlarına yansımıştır.

Aliağaoğlu ve Uzun (2011)'a göre, Türkiye'deki caddelerin genel sınıflandırılması Çizelge 1'de verilmektedir:

Çizelge 1. Türkiye'deki cadde sınıflandırmaları (Aliağaoğlu ve Uzun, 2011)

\begin{tabular}{|c|}
\hline 1- CUMHURIYETLE ILGILI CADDELER \\
\hline 1.1. Cumhuriyet caddeleri \\
\hline 1.2. Cumhuriyetin önemli şahısları ile ilgili caddeler \\
\hline 1.3. Zafer caddeleri \\
\hline 1.4. Kurtuluş günü caddeleri (Cumhuriyet takvimi caddeleri) \\
\hline 1.5. Kavramsal cumhuriyet caddeleri \\
\hline 2- ŞEHiTLER CADDESi \\
\hline 3- DOSTLUK-KARDEŞLiK CADDELERI \\
\hline 4- YER/YÖN BELIRTEN CADDELER \\
\hline 4.1. Nirengi noktaları ile ilgili caddeler \\
\hline 4.2. Eski ve yeni arazi kullanım ile ilgili caddeler \\
\hline 4.3. Fosil caddeler \\
\hline 5- SAYISAL CADDELER (MATEMATiK ADLANDIRMA iLE İGiLi CADDELER) \\
\hline 6- ÖNEMLi ŞAHISLAR \\
\hline 6.1. Yerel şahıslar \\
\hline 6.2. Ulusal şahıslar \\
\hline
\end{tabular}

Özkan ve Yoloğlu (2005)'na göre ulus devletlerin kuruluş süreçlerinde ulus inşasında, tarihin yeniden kurgulanması gerektiğinin, bir topluluk bilincinin oluşturulup ortak bir geçmişe sahip olunduğu inancının benimsenmesi gerekmektedir. Bu noktada dilin yeni isimlerinin de kentte yerini alması gerekmektedir. Türkiye'de 1923-1950 yılları arasında ulus devletleşme cumhuriyet adı ve onunla bağlantılı olaylar, kişiler ve günler ulusal mekânların düğüm noktaları olan şehirlerde caddelere yansımıştır.

Geçmişten günümüze güvenlik güçlerinde çalışıp şehit olan veya görevi başında hayatlarını kaybeden sivil çalışanların kentte isimlendirildiği görülmektedir. Buna en yakın örnekler, 15 Temmuz 2016 darbe girişimi sonucu İstanbul Boğaziçi Köprüsü’nün isminin 15 Temmuz Şehitler Köprüsü olarak, Ankara'da Kızılay Meydanı'nın 15 Temmuz Kızılay Milli İrade Meydanı olarak ve 10 Ekim 2015 terör saldırısı sonucu Ankara Gar Meydanı́nın Demokrasi Meydanı olarak değişmesidir. 
Aliağaoğlu ve Uzun (2011)'a göre dostluk kardeşlik caddeleri tarihi ve kültürel nitelikler taşıyarak, Türklerin yerleştiği geniş alanların coğrafyası hakkında bilgi vermekte, soy bağını ifade etmektedir. Yer-yön belirten caddelerin, anıtsal ve ideolojik anlam taşımayan daha çok kendi bitişiğindeki ve yakın çevresindeki fiziki özelliklerden, nirengi noktalarından ve kentli için sembol olan alanlardan iz taşıdığı görülmektedir.

Matematik adlandırma cadde ve bulvar adlandırmasının görüldüğü caddelere daha çok büyük şehirlerin yeni gelişen kenar alanlarında ve büyük olmayan şehirlerde organize sanayi bölgelerinde rastlanmaktadır (Aliağaoğlu ve Uzun 2011). Bu yöntemle sokakların adlandırılması daha kolay hale gelse de Pérouse'un (2011) ifade ettiği, isimsiz bir yoldan isim verilmiş bir yola geçişin kent dokusunu istikrarlı hale getirerek, kentin biçimlenme süreci yaşadığını göstermesi, sayısal adlandırmanın yetersiz olduğunu göstermektedir.

Aliağaoğlu ve Uzun (2011)'a göre geçmişte topluma hizmeti bulunmuş, kendi alanlarında ve belirli dönemlerde ün yapmış ulusal ölçekte şahıslar (devlet adamı, sanatçı, sporcu, asker vb.) ve o şehirde yaşamış ve şehre çeşitli yollarla katkısı bulunmuş (hizmet, bağış vb.) yerel ölçekteki şahısların isimleri sıklıkla cadde ve bulvar adlandırmalarında karşımıza çıkmaktadır. Kentteki mekânların şahıs isimlerine yönelik değişimi, isimlendirme eylemlerinin unutturma, hatırlatma ve sahiplendirme üzerinden oluştuğu düşüncesiyle son zamanlarda büyük tartışma konularına yer açmıştır. Buna örnek olarak çalışma alanımız olan Ankara Tandoğan Meydanı'nın Anadolu Meydanı olarak değişmesi gösterilebilir.

\subsubsection{Cadde-Sokak-Meydan İsimlendirmelerinin Kent Belleği Üzerindeki Etkisi}

Sokak, cadde ve meydan isimleri halkla etkileşimin sağlandığı kamusal alanlardır. Mekân, yaşanmışıkları somutlaştırarak görünür hale getirmekte ve kullanıcıların dün ile bugün arasında bağlantı kurmasına olanak sağlamaktadır. Bu nedenle kentin kimliğinde ve toplumsal bellekte önemli bir yere sahiptirler. Ancak bu mekânlar, geçmişten günümüze farklı etkenlerden dolayı müdahalelere maruz kalmışlardır. Mekâna yapılan müdahaleler, mekâna yüklenen 'kullanıcıların kullanım alışkanlıklarının bir parçası haline gelen ve hayat biçimiyle entegreolan' anlamlarıyla, kent belleği üzerinde etkiye sahiptir. Mekâna yapılan bir müdahale biçimi de isim değişikliğidir. Özkan ve Yoloğlu (2005)'na göre mekânların isimlendirilmesi başlangıçta kendiliğinden gelişmiş, dil ile beraber değişiklikler geçirmiş ve geleceğe aktarılarak, mekâna ilişkin belleğin, çevreye ve geleceğe taşınması sağlanmıştır. Ancak zamanla kolektif belleğin hatırlanış veya unutuluş için kullanıldığı ve bu sayede toplumun ortak bir belleğinin oluşmasına sebep olduğu düşüncesi kolektif belleğin algı yönetiminde kullanılmasına zemin hazırlamış, isimlendirme bellek oluşturma da, siyasi bir araç olarak kullanılır hale gelmiştir.

Bir sokak isminin bellekte yer edinebilmesi için o ismin, yaşamın içinden çıkıp toplum tarafından benimsenmiş olması gerekir. Dış etkilerle egemen güçler tarafından şekil değiştiren sokak, cadde veya meydan isimlerinin ömrü, yansıttığı ideolojilerin kalıcılığıyla doğru orantılıdır (Yoloğlu ve Özkan, 2005).

Cadde-sokak-meydan isimlendirmelerinin kent belleği üzerindeki etkilerinin daha iyi gözlemlenmesinde Ankara'da önemli konuma sahip farklı zamanlarda ve farklı nedenlerle isim değişikliğine uğramış 3 meydan örnek verilebilir.

Bu örneklerden birincisi; Türkiye'de 15 Temmuz'da yaşanılan askeri darbe girişiminin ardından Ankara Belediye Meclisi kararı ile 15 Temmuz Kızılay Milli İrade Meydanı olarak değişikliğe uğrayan Kızılay Meydanıdır. Yapılan bu isim değişikliği 15 Temmuz'un bu ülkenin tarihi açısından önemli bir gün olarak hatırlanması istendiğini göstermektedir. 15 Temmuz gecesi, askerleri durdurmak için sokağa çıkan pek çok sivil insan, silahlı askerler tarafından öldürülmüştür. Darbe girişimden sonra Kızılay Meydanı'nın adı; 'halkın demokrasiye sahip çıktığını, 15 Temmuz şehitlerinin gereksiz yere ölmediğini, toplumsal bir ortak hedef uğruna savaşarak yaşamını yitirdiğini ve 15 Temmuz'un Türkiye için herhangi bir gün olmadığını hatırlatmak' amacıyla Ankara Büyükşehir Belediyesince değiştirilmiştir. Yapılan bu isim değişikliği meydanın farklı anlamlar kazanmasına yeni bir olayın sembolü haline 
gelmesine olanak sağlamıştır. Ancak Kızılay Meydanı isminin kentli tarafından benimsenmiş bir isim olması, yapılan isim değişikliğinin kentsel bellekte nasıl yer edeceği bilinmemektedir.

İkinci olarak; Ankara'da siyasi parti mitingine ve eyleme ev sahipliği yapmasıyla şehrin sembol mekânlarından biri haline gelen Tandoğan Meydanı isminin 14 Nisan 2015 tarihinde Anadolu Meydanı olarak değiştirilmesi örnek gösterilebilir. Tandoğan Meydanı ismi eski Ankara valisi Nevzat Tandoğan'dan gelmektedir. Meydanın isim değiştirme süreci 2012 yılında Nevzat isminin kaldırılması ve sonra Anadolu Meydanı olmasıyla son bulmuştur. Bu değişiklik, kentlinin yaşadığı bir olay ile uygulanmamış, dışarıdan bir müdahale ile uygulanmıştır. Bu yönden diğer iki örnekten farklılaşmaktadır.

Son örnek; 10 Ekim 2016'da Ankara'da meydana gelen ve 99 kişinin ölümüne sebep olan patlamanın sonucunda ismi değişikliğe uğrayarak Demokrasi Meydanı olan Ankara Garı Meydanı'dır. Ankara Garı Meydanı patlamada hayatını kaybedenleri hatırlamak ve terör eylemlerine karşı tepki göstermek amacıyla isim değişikliğine uğramıştır. 10 Ekim tarihinde yaşanan olay ile meydan, kentli için gar meydanı olmanın ötesinde derin anlamlar kazanmıştır.

Toplum kendi dinamikleriyle oluşan isimlerin sürekliliğini koruduğu için bellek mekân olarak nitelendiren alanlarda meydana gelen isim değişikliklerinin kentli tarafından benimsenmesi zaman almaktadır. Bu doğrultuda çalışmanın ikinci bölümünde Kızılay, Tandoğan ve Ankara Garı Meydanı'ndaki isim değişikliklerine yönelik anket çalışması yapılmıştır.

\subsection{Ankara'da İsim Değişikliğine Uğrayan Meydanların Kent Kimliğine Etkisine Yönelik Alan Çalışması}

Meydanlardaki isim değişikliklerinin kent belleğine etkisinin daha iyi gözlemlenmesi için literatür çalışmasının yanında alan çalışmasına yer verilmiştir. Alan çalışması olarak Ankara'da farklı yerlerde, farklı zamanlarda ve farklı nedenlerle isim değişikliğine uğramış 3 meydan seçilmiştir. Bunlardan birincisi Ankara için geçmişten günümüze merkez konumunda olan 15 Temmuz Kızılay Milli İrade Meydanı, ikincisi çeşitli eylemlere ev sahipliği yapmasıyla Ankara'nın sembol mekânlarından biri haline gelen Anadolu Meydanı ve son olarak 10 Ekim 2016'da gerçekleşen patlamayla adını duyuran Demokrasi Meydanı'dır. Bu üç meydan için 2016 Kasım ayında 1 haftalık zaman dilimin içinde farkı gün ve saatlerde 100 adet anket çalışması yapılmış ve kullanıcıların çeşitli gruplardan (cinsiyet, yaş, meslek gibi) olmasına özen gösterilmiştir.

Ilk örnek alan olan 15 Temmuz Kızılay Milli İrade Meydanı'nda 17 kız, 17 erkekten oluşmak üzere toplam 34 anket yapılmıştır. Anket yapılan kişilerin yaş aralığı 18 ile 63 arasında değişmekte ve ortalama yaş değeri $36^{\prime}$ dır. Kişilerin kaç yıldır Ankara'da yaşadığına bakıldığında en düşük değer 2, en yüksek değer 53 ve ortalama değer 23'tür. Anket yapılan kişilerin \%35'i (12 kişi) doğuştan bu yana Ankara'da yaşamaktadır, kalan \%65'lik (22 kişi) kısım ise farklı zamanlarda farklı yerlerden Ankara'ya gelmişlerdir (Şekil 2).

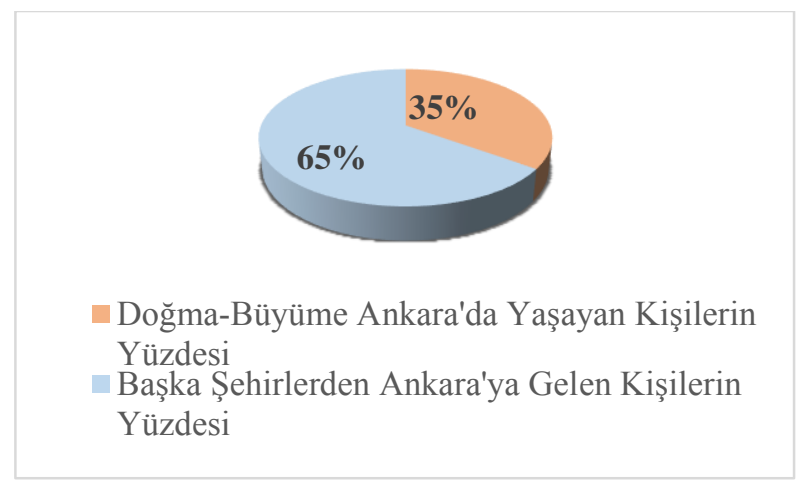

Şekil 2. 15 Temmuz Kızılay Milli İrade Meydanı'nda anket yapılan kişilerin Ankara'da doğup-büyüme oranı

Anket yapılan 34 kişiden 9'u 'Bu meydanın adı nedir?' sorusuna 15 Temmuz Kızılay Milli İrade Meydanı yanıtını verirken, kalan 25 kişi Kızılay Meydanı yanıtını vermiştir. Bunun sonucunda Şekil 3'te de görüldüğü gibi anket yapılan kişilerin yalnızca \%26'sı 15 Temmuz Kızılay Milli İrade Meydanının ismini doğru söylemiştir. 


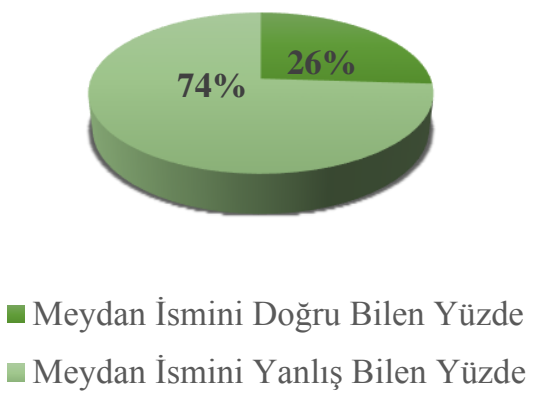

Şekil 3. Anket yapılan kişilerin 15 Temmuz Kızılay Milli İrade Meydanı'nın ismini bilip bilmeme durumu

Anket yapılan 34 kişiden 25'i 'Bulunduğunuz meydanın isim değişikliklerinden haberiniz var mı?' sorusuna evet yanıtını verirken kalan 9'u hayır yanıtını vermiştir. Bu durumda anket yapılan kişilerin \%73'ü 15 Temmuz Kızılay Milli İrade Meydanı'nın isim değişikliğinden haberdar iken, kalan \%27'lik kısmı bu değişikliği bilmemektedir.

Ankette yer alan 'Bulunduğunuz meydanının adı nedir?' ve 'Bulunduğunuz meydanın isim değişikliklerinden haberiniz var mı?' soruları, doğduğundan bu yana Ankara'da yaşayan kişiler için ayrıca değerlendirilmiş böylece kentsel bellek kavramının, kullanıcının mekânda geçirdiği süre zarfıyla ve o mekândaki anıları ile etkisinin saptanması amaçlanmıştır. Bu doğrultuda doğuştan bu yana Ankara'da yaşayan 12 kişiden yalnızca 2'si 'Bulunduğunuz meydanının adı nedir?' sorusuna 15 Temmuz Kızılay Milli İrade Meydanı yanıtını vermiştir. 'Bulunduğunuz meydanın isim değişikliklerinden haberiniz var mı?’ sorusuna ise 8 kişi evet yanıtını vermiştir. Bu sonuçlar değerlendirildiğinde değişiklikten haberdar olan 8 kişinin 6'sı hala Kızılay Meydanı adını kullanmayı tercih etmektedir.

Yapılan anketler 15 Temmuz Kızılay Milli İrade Meydanı'nın kentliler için hala Kızılay Meydanı olarak anıldığını göstermiştir. Kızılay Meydanı Ankara'nın kentleşmesi sürecinde önemli bir odak noktası olmuş, zamanla birçok değişiklik geçirmiş ama kentliyle kurduğu bağı hiçbir zaman kaybetmemiştir. Ankara'da yaşayan her birey Kızılay Meydanı'yla ilgili bir yaşanmışlığa sahiptir. Bu nedenle, yapılan değişiklik sonucu kentlinin algısında Kızılay Meydanı'nın yok olup 15 Temmuz Kızılay Mili İrade Meydanı'nın oluşması 6 aylık kısa bir süre içinde olanaksızdır.

15 Temmuz Kızılay Milli İrade Meydanı'nın Ankara için önemli bir yer olması, anket sonuçlarına, isim değişikliğinin kentli tarafından yüksek oranda bilinmesiyle bir başka şekilde yansımıştır. Meydanın, kentlilerin farkı kullanımlarına olanak sağlaması ve kentin aktarma merkezi konumunda yer alması, kişilerin meydanla olan temasını güçlendirmekte, bireylerin değişiklikleri daha kısa zamanda kavramasına olanak sağlamaktadır. Buna örnek olarak isim değişikliğinin hemen ardından otobüsmetro duraklarının ve levhaların da isminin değişmesi verilebilir. Aynı zamanda isim değişikliğine sebep olan 15 Temmuz darbe girişiminin, çok yakın geçmişte büyük etkiler uyandırması kentlinin büyük bir kısmının, bu isim değişikliğini kamuoyu yoluyla öğrenmesini sağlamıştır.

Anket sonuçlarının, doğduğundan bu yana Ankara'da yaşayanlar için ayrıca değerlendirilmesi, kentte geçirilen zamanın yaşanmışlıklarla orantılı olarak isim değişikliğini benimseme sürecine etki ettiğini göstermiştir. Genel anket sonuçlarına göre Ankara'da doğup büyüyenlerin meydanın yeni ismini daha düşük oranda doğru bildiği ve meydana gelen isim değişikliğinden daha düşük oranda haberdar olduğu görülmüştür. Bunun yanında genel anket sonuçlarına göre Ankara'da doğup büyüyenlerin isim değişikliğini bilip eski ismi kullanmayı tercih etme yüzdesi daha yüksektir.

İkinci örnek alanımız olan Anadolu Meydanı'nda 16 kız, 17 erkekten oluşmak üzere toplam 33 anket yapılmıştır. Anket yapılan kişilerin yaş aralığı 21 ile 62 arasında değişmekte ve ortalama yaş değeri 36'dır. Kişilerin kaç yıldır Ankara'da yaşadığına bakıldığında en düşük değer 5, en yüksek değer 62 ve ortalama değer 24'tür Anket yapılan kişilerin \%42'si (14 kişi) doğuştan bu yana Ankara'da yaşamaktadır kalan \%58'lik (19 kişi) kısım ise farklı zamanlarda farklı yerlerden Ankara'ya gelmişlerdir (Şekil 4). 


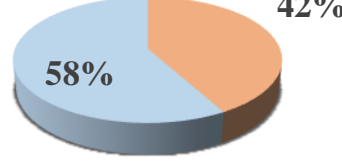 \\ Doğma-Büyüme Ankara'da Yaşayan \\ Kişilerin Yüzdesi \\ Başka Şehirlerden Ankara'ya gelen \\ Kişilerin Yüzdesi}

Şekil 4. Anadolu Meydanı́nda anket yapılan kişilerin Ankara'da doğup-büyüme oranı

Anket yapılan 33 kişiden 12'si 'Bu meydanın adı nedir?' sorusuna Anadolu Meydanı yanıtını verirken, kalan 25 kişi Tandoğan Meydanı yanıtını vermiştir. Bunun sonucunda Şekil 5'te de görüldüğü gibi anket yapılan kişilerin yalnızca \%36'sı Anadolu Meydanının ismini doğru söylemiştir.

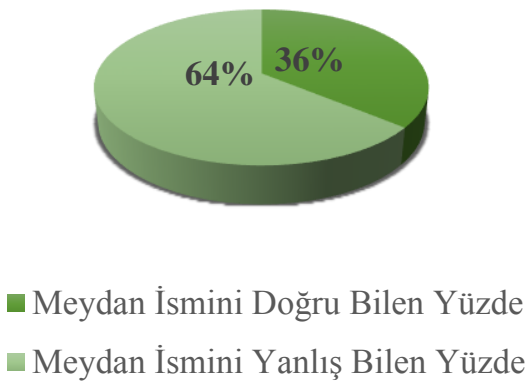

Şekil 5. Anket yapılan kişilerin Anadolu Meydanı'nın ismini bilip bilmeme durumu

Anket yapılan 33 kişiden 19'u 'Bulunduğunuz meydanın isim değişikliklerinden haberiniz var mı?' sorusuna evet yanıtını verirken kalan 14'ü hayır yanıtını vermiştir. Bu durumda anket yapılan kişilerin \%57'si Anadolu Meydanı'nın isim değişikliğinden haberdar iken, kalan \%43'lük kısmı bu değişikliği bilmemektedir. İsim değişikliğinden haberdar olan \%57'nin içinde yer alan her birey yeni ismi doğru şekilde ifade edebilmiştir. Bu sonuçlar değerlendirildiğinde isim değişikliğinden haberdar olan 19 kişiden 12 'sinin yeni ismi kullandığı görülmektedir.

Ankette yer alan 'Bulunduğunuz meydanının adı nedir?' ve 'Bulunduğunuz meydanın isim değişikliklerinden haberiniz var mı?' soruları, doğduğundan bu yana Ankara'da yaşayan kişiler için ayrıca değerlendirilmiş böylece kentsel bellek kavramının, kullanıcının mekânda geçirdiği süre zarfıyla etkisinin saptanması amaçlanmıştır.

Bu doğrultuda doğuştan bu yana Ankara'da yaşayan 14 kişiden yalnızca 2'si 'Bulunduğunuz meydanının adı nedir?' sorusuna Anadolu Meydanı yanıtını vermiştir. 'Bulunduğunuz meydanın isim değişikliklerinden haberiniz var mı?' sorusuna ise 8 kişi evet yanıtını vermiştir. Bu sonuçlar değerlendirildiğinde değişiklikten haberdar olan 8 kişinin 6 'sı hala Tandoğan Meydanı adını kullanmayı tercih etmektedir.

Anadolu Meydanı'nın Ankara kenti için önemli bir nokta olması, farklı işlevlerle donatılmış olması ve bulundurduğu üniversitelerle öğrenci potansiyeline sahip olması geçirdiği isim değişikliği sürecinin ve yeni ismin kentli tarafından bilinmesine olanak sağlamıştır. Anket sonuçlarına göre meydan ismini doğru bilen kişi sayısı anket yapılanların yarısından az (\%36) olup Tandoğan ismini kullanan oran çoğunluktur (\%64). Bu sonuç meydana gelen isim değişikliğinin kent belleğinde tam olarak yer edinemediğini göstermektedir.

Anadolu meydanında yapılan anket sonuçlarının, doğduğundan bu yana Ankara'da yaşayanlar için ayrıca değerlendirilmesi, kentte geçirilen zamanın yaşanmışlıklarla orantılı olarak isim değişikliğini benimseme sürecine etki ettiğini göstermiştir. Genel anket sonuçlarına göre Ankara'da doğup büyüyenlerin meydanın yeni ismini daha düşük oranda doğru bildiği (\%14'e \%36) ve meydana gelen 
isim değişikliğinden eşit oranda (\%57 - \%57) haberdar olduğu görülmüştür. Bunun yanında genel anket sonuçlarına göre Ankara'da doğup büyüyenlerin isim değişikliğini bilip eski ismi kullanmayı tercih etme yüzdesi büyük farkla daha yüksektir (\%75'e \%36).

Anadolu Meydanı'ndaki sonuçlar 15 Temmuz Milli İrade Meydanı'ndaki sonuçlarla kıyaslandığında; kentlinin Anadolu Meydanı ismine 15 Temmuz Milli İrade Meydanı ismine oranla daha hâkim olduğu ve yeni ismi kullanma oranının daha yüksek olduğu görülmektedir. Buna neden olan etken Anadolu Meydanı'nda ki isim değişikliğinin daha eski zamanda yapılmış olması, otobüs ve metro duraklarında levhalardaki değişikliği sık sık görmesidir.

Üçüncü örnek alanımız olan Demokrasi Meydanı́nda 17 kız, 16 erkekten oluşmak üzere toplam 33 anket yapılmıştır. Anket yapılan kişilerin yaş aralığı 20 ile 53 arasında değişmekte ve ortalama yaş değeri 34 tür. Kişilerin kaç yıldır Ankara'da yaşadığına bakıldığında en düşük değer 2 en yüksek değer 44 ve ortalama değer 19'dur. Anket yapılan kişilerin \%33'ü (11 kişi) doğuştan bu yana Ankara'da yaşamaktadır, kalan \%67'lik (22 kişi) kısım ise farklı zamanlarda farklı yerlerden Ankara'ya gelmişlerdir (Şekil 6).

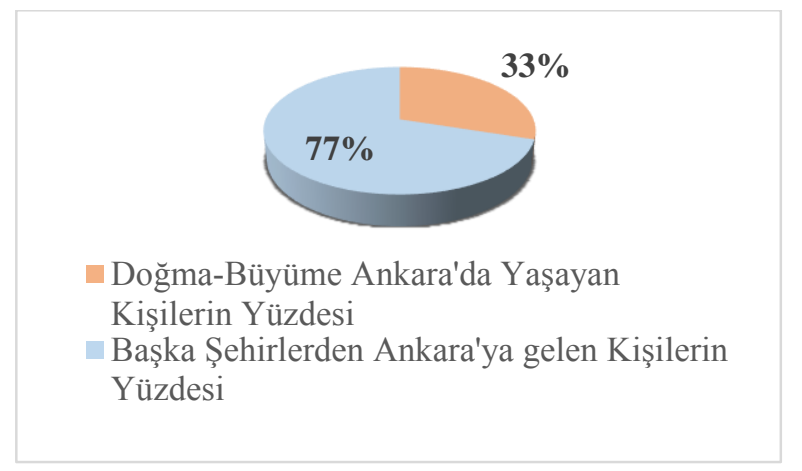

Şekil 6. Demokrasi Meydanında anket yapılan kişiler içindeki Ankara'da doğup-büyüme oranı

Anket yapılan 33 kişiden 3'ü 'Bu meydanın adı nedir?' sorusuna Demokrasi Meydanı yanıtını verirken, kalan 30 kişiden 7'si yanlış yanıtlamış, 23'ü ise bilmediğini söylemiştir. Bunun sonucunda Şekil 7'de de görüldüğü gibi anket yapılan kişilerin sadece \%9'u Demokrasi Meydanının ismini doğru söylemiştir.

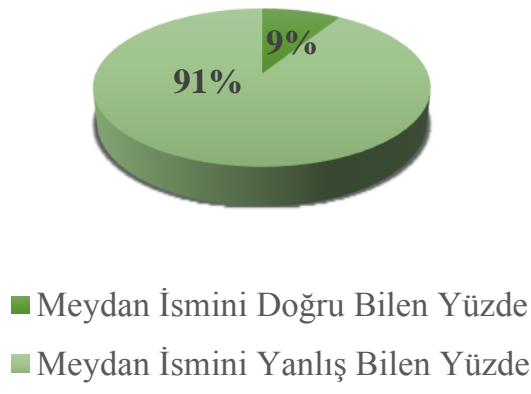

Şekil 7. Anket yapılan kişilerin Demokrasi Meydanı'nın ismini bilip bilmeme durumu

Anket yapılan 33 kişiden 6'sı 'Bulunduğunuz meydanın isim değişikliklerinden haberiniz var mı?' sorusuna evet yanıtını verirken kalan 27'si hayır yanıtını vermiştir. Bu durumda anket yapılan kişilerin \%18'i Demokrasi Meydanı'nın isim değişikliğinden haberdar iken, kalan \%82'lik kısmı bu değişikliği bilmemektedir. İsim değişikliğinden haberdar olan \%18'nin içinde olan bireylerin arasında 1 birey dışında herkes yeni ismi doğru şekilde ifade edebilmiştir. Bu sonuçlar değerlendirildiğinde isim değişikliğinden haberdar olan 6 kişiden 3'ünün yeni ismi kullandığı görülmektedir.

Ankette yer alan 'Bulunduğunuz meydanının adı nedir?' ve 'Bulunduğunuz meydanın isim değişikliklerinden haberiniz var mı?' soruları, doğduğundan bu yana Ankara'da yaşayan kişiler için ayrıca değerlendirilmiş böylece kentsel bellek kavramının, kullanıcının mekânda geçirdiği süre zarfıyla etkisinin saptanması amaçlanmıştır. 
Bu doğrultuda doğuştan bu yana Ankara'da yaşayan 11 kişiden yalnızca 1'i 'Bulunduğunuz meydanının adı nedir?' sorusuna Demokrasi Meydanı yanıtını vermiştir. Aynı şekilde 'Bulunduğunuz meydanın isim değişikliklerinden haberiniz var mı?' sorusuna da 1 kişi evet yanıtını vermiştir. Evet yanıtını veren bu kişinin Demokrasi Meydanı ismini kullanmayı tercih ettiği görülmüştür.

Demokrasi Meydanı'nda yapılan anketler kentlinin meydana dair genel bir fikrinin olmadığını göstermiş̧ir. Bunun nedenleri arasında Demokrasi Meydanı'nın anketteki diğer meydanlara oranla daha transit bir işleve sahip olması ve kentliyle mekân temasını tam olarak kuramamasıdır.

Üç meydan için anketteki 'bulunduğunuz meydanın adı nedir?' sorusu incelendiğinde (Tablo II);

Verilen cevaplar, kentlilerin meydanların yeni ismini benimsediğini söylemek için yetersiz olduğu göstermektedir. Doğru cevabın en çok Anadolu Meydanı'nda, en az ise Demokrasi Meydanı'nda alındığı görülmüştür. Anadolu ve 15 Temmuz Kızılay Milli İrade Meydanları'nda soruya yanlış cevap verenler meydanların eski isimlerini söylemiştir. Ancak Demokrasi Meydanı'nda 23 kişi 'bilmiyorum' yanıtını vererek \%69'luk çoğunluğu oluşturmuştur. Bu durum Demokrasi Meydanı'nın kentli tarafından yeteri kadar bilinmediğini göstermektedir. Anadolu Meydanının kentli tarafından diğer meydanlara oranla daha çok benimsenmesinin nedeni ise yapılan isim değişikliğinin diğer değişikliklerinden göre daha eski zamanlı olmasıdır.

Anket sorusu yalnızca Ankara'da yaşamış insanlar için çapraz sorgulanıp değerlendirildiğinde (Çizelge 2);

15 Temmuz Kızılay Milli İrade Meydanı'nda ve Anadolu Meydanı'nda oranın daha düştüğü görülmektedir. Bunun nedeni meydanların Ankaralıların kent belleğinde daha fazla anlama sahip olması ve belleğin isim değişikliğine uyum sağlayamamasıdır.

Çizelge 2. 3 meydan için meydan ismini doğru bilme oranları

\begin{tabular}{|l|l|l|}
\hline \multirow{2}{*}{} & \multicolumn{2}{|l|}{$\begin{array}{l}\text { Meydan ismini doğru } \\
\text { bilen }\end{array}$} \\
\cline { 2 - 3 } & Genel & $\begin{array}{l}\text { Ankara'da doğup } \\
\text { büyüyen }\end{array}$ \\
\hline $\begin{array}{l}\text { 15 Temmuz Kızılay } \\
\text { Milli Irade Meydanı }\end{array}$ & $26 \%$ & $16 \%$ \\
\hline Anadolu Meydanı & $36 \%$ & $14 \%$ \\
\hline Demokrasi Meydanı & $9 \%$ & $9 \%$ \\
\hline
\end{tabular}

\section{Sonuç}

Bellek kimlikten beslenen bir olgudur. Zaman içinde kimliği oluşturan bileşenlerin değişmesi belleğin de değişik şekillerde karşımıza çıkmasına yol açmaktadır. Belleğin toplumsal boyutu, bireyin yapı çevre ile etkileşiminin incelenmesini sağlamış ve kentsel bellek kavramı doğmuştur.

Mekân bireylerin diğer bireylerle etkileşimini sağlar, farklı eylemlerin gerçekleştirilmesine imkân tanır ve içindeki yaşanmışlıkları, anıları biriktirerek kendi ruhunu oluşturur. Mekâna yüklenen bu anlamlar, mekânın toplumla ve geçmiş-gelecek arasında bağ kurmasını sağlayarak kentin belleğini oluşturur. Kent kolektif belleğinin tamamıdır. Bundan dolayı günümüzde egemenler hâkimiyetini sürdürmek için kenti bir araç olarak kullanmaya başlamıştır. Bu doğrultuda kent ve kent parçaları müdahaleye uğramaktadır. Bu müdahale biçimlerinden biri de isim değişikliğidir. Sokaklara-caddelere-meydanlara verilen adlar günümüzde geleneksel işlevinden farklı olarak belli bir ideolojinin sembolü haline gelmiştir.

Bu çalışma isim değişikliğinin kent belleğindeki etkisini içermektedir. Farklı zamanlarda, farklı nedenlerle değişikliğe uğrayan üç meydan (15 Temmuz Kızılay Milli İrade - Anadolu - Demokrasi) üzerinden yapılmış anket sonuçlarıyla; kentlinin meydanı eski ismiyle mi yeni ismiyle mi andığı, isim değişiklerinden ne kadar haberdar olduğu, haberdar olanların eski ismi mi yoksa yeni ismi mi kullanmayı tercih ettiği sorularına yanıt aranmıştır. 
Yapılan anketler doğrultusunda; kentlinin 15 Temmuz Kızılay Milli İrade Meydanı'na ve Anadolu Meydanı'na hâkim olduğu fakat Demokrasi Meydanı ile ilgili genel fikirlerinin olmadığı görülmüştür. Bu durum mekânın sahip olduğu özellikler ve geçmişten günümüze taşıdığı anılar ölçüsünde kentlinin belleğine yer ettiğini göstermektedir. Anket sonuçları değerlendirildiğinde; 15 Temmuz Kızılay Milli İrade Meydanı'nda ve Anadolu Meydanı'nda, kentlinin çoğunluğun eski isimleri kullandığı tespit edilmiştir. Bu sonuç; yapılan isim değişikliklerinin şu ana kadar geçen zaman diliminde kentlinin belleğindeki isimleri değiştiremediğini, kentlinin mekâna yönelik algısının güçlü olduğunu göstermektedir.

Yapılan anket sonuçlarına göre 15 Temmuz Kızılay Milli İrade Meydanı ve Anadolu Meydanı'nda kentlinin yapılan isim değişikliğini yüksek oranda bildiği görülmüştür. Bunun nedeni olarak her iki meydanın da gerek konumuyla gerekse taşıdığı farklı işlevlerle günlük yaşamda kentli için önemli bir yer oluşturması gösterilebilir. Bunun yanında 15 Temmuz Kızılay Milli İrade Meydanı isim değişikliğinin Anadolu Meydanı'ndaki isim değişikliğinden daha yüksek oranda bilinmesi 3 etken üzerinden değerlendirilmiştir. Bu etkenler; 15 Temmuz Kızılay Milli İrade Meydanı'nın daha fazla insana temas etmesi ve daha farklı kullanıı profilinden oluşması, isim değişikliğine neden olan olayın doğrudan kentliyi etkileyen ve kentli üzerinde derin etkiler bırakması ve isim değişikliğinin daha güncel olmasıdır.

Anket sonuçlarına göre isim değişikliğini bildiği halde eski ismi kullanmayı tercih etme yüzdesi 15 Temmuz Kızılay Milli İrade Meydanı'nda oldukça yüksektir. Bunun nedeni; meydanın geçmişten günümüze Ankara için önemli bir merkez özelliği taşıması ile kentlinin meydanda yaşanmışığının ve anılarının oldukça fazla olması, Kızılay isminin kentlinin dilinde ve belleğinde alışkanlık olması ve yeni ismin kent belleğinde yer etmesi için geçen zamanın yetersiz olması olarak değerlendirilmiştir. 15 Temmuz Kızılay Milli İrade Meydanı ve Anadolu meydanındaki yeni ismi kullanma oranı karşılaştırıldığında, Anadolu meydanında isim değişikliğinden haberdar olanların yeni ismi daha yüksek oranda kullandığı görülmektedir. Bunun nedeni zaman faktörünün de etkisiyle kişilerin, Anadolu meydanı ismine 15 Temmuz Kızılay Milli İrade Meydanı ismine oranla daha hâkim olması olarak değerlendirilmiştir.

Doğduğundan bu yana Ankara'da yaşayanların verdiği sonuçlar genel sonuçlara göre değerlendirildiğinde, Ankaralıların; 15 Temmuz Kızılay Milli İrade Meydanı ve Anadolu Meydanı'nda eski ismi daha yüksek oranda kullandığı, 15 Temmuz Kızılay Milli İrade Meydanı ve Demokrasi Meydanı'nda isim değişikliğini daha düşük oranda bildiği, 15 Temmuz Kızılay Milli İrade Meydanı ve Anadolu Meydanı'nda değişikliği bilip eski ismi kullanma yüzdesinin daha yüksek olduğu göstermiştir. Bu sonuç, literatürde bahsedilen mekândaki yaşanmışlığın, anıların ve alışkanlıkların, kentlinin isim değişikliğini benimseyip-benimsememesinde etkili olduğunu göstermektedir.

Literatür araştırması ve anket sonuçlarına göre kentlilerin mekân üzerindeki isim değişikliklerine karşı farklı tepkiler verdiği söylenebilir. Bu farklılı̆̆ sağlayan etkenler üç boyutta ele alınabilir. Birinci boyut mekânın özellikleri ve insana erişebilirliğidir. İkinci boyut insanın o mekâna yüklediği anlamlar ve belleğinde yer eden imgelerdir. Üçüncü boyut ise kentin ve kentlinin ideolojisidir. Bu kapsamda kent mekânındaki isimlendirmenin bu üç etken doğrultusunda oluşması gerektiği, yeni isimlerin kent belleğinde yer edebilmesi için insanla etkileşimden ortaya çıkması gerektiği söylenebilir.

Bu çalışmada kent mekânına yapılan müdahalelerden biri olan isim değişikliği, kentsel bellek kapsamında araştırılmış, Ankara'daki isim değişikliklerinin henüz kentli tarafından tam olarak benimsenmediği saptanmıştır. Elde edilen sonuçlar, kentlinin isim değişikliğine verdiği uyum bağlamında önem taşımakta, kentsel belleğe etki eden etkenleri ortaya koymaktadır.

\section{Kaynaklar}

Aliağaoğlu, A. ve Yiğit, Y (2013). Balıkesir'de Şehirsel Toponimi: Cadde Adları, Doğu Coğrafya Dergisi Yayınları, 30, 311-330.

Ayataç, H. ve Araz, S. (2015). Cadde Ve Sokak Adlandırmalarının (Kentsel Toponimi) Kentsel Kimlik Üzerindeki Etkilerinin Değerlendirilmesi; Ayvalık Ve Cunda Örneği, İstanbul, İstanbul Teknik Üniversitesi 
Bayhan, B. (2013). Hafıza Mekânları, Arkitera, http://www.arkitera.com/haber/18781/hafiza-mekanlari, Erişim Tarihi: 22.11.2016

Bayramoğlu, N. ve Ocakçı, M. (2010). Kullanıcı Algısı Bağlamında Kentsel Kimlik: Barbaros Bulvarı - Büyükdere Kentsel Aksı, İstanbul, İstanbul Teknik Üniversitesi

Baysan, S. ve Kara, A. (2014). Aydın'da Mahalle, Bulvar, Cadde ve Sokak Adları: Şehirsel Toponimik Özellikler, Coğrafi Bilimler Dergisi Yayınları, 12(1), 23-48.

Çakır, H. ve Gönül, B. (2015). Tarihi Yapılarda Mekansal Belleğin Korunması: İzmit Seka Selüloz Ve Kağıt Fabrikasının Dönüşümü, Beykent Üniversitesi Fen Ve Mühendislik Bilimleri Dergisi Yayınları, 8(2), 85-110.

Çalak, I. (2012). Kentsel ve Kolektif Belleğin Sürekliliği Bağlamında Kamusal Mekanlar: ULAP Platz Örneği, Tasarım+Kuram Yayınları, 13, 34-47.

Işıkhan, T. (2008), Gaziantep Yer Adlarının Halkbilimi Bakımdan Değerlendirilmesi, Ankara, Gazi Üniversitesi

Levent, Y. (2016). Mekânın Belleğinden Bellek Mekânlarına: Korumada Değişen Değer Anlayışı Ve Kültürel Miras, Mersin, Mersin Üniversitesi.

Özkan, M, ve Yoloğlu, A. (2005). Bir Bellek Projesi Olarak Sokak İsimlendirmesi-Ankara Örneği, ŞPO Yayınları, 4, 54-60.

Topçu, K. (2011). Kent Kimliği Üzerine Bir Araştırma: Konya Örneği, Uluslararası İnsan Bilimleri Dergisi Yayınları, 8(2), 1048-1072. 